\title{
Fibroblast Growth Factor 9
}

National Cancer Institute

\section{Source}

National Cancer Institute. Fibroblast Growth Factor 9. NCI Thesaurus. Code C26146.

Fibroblast growth factor 9 (208 aa, $23 \mathrm{kDa}$ ) is encoded by the human FGF9 gene. This protein is involved in embryonic development, cell proliferation, cell differentiation and cell migration. 